Abstracta Iranica Abstracta Iranica

Revue bibliographique pour le domaine irano-aryen

Volume 42-43 | 2021

Comptes rendus des publications de 2019-2020

\title{
David Durand-Guédy, Roy Mottahedeh, Jürgen Paul (eds.). Cities of Medieval Iran
}

\section{Shivan Mahandrajarah}

\section{(2) OpenEdition \\ 1 Journals}

\section{Electronic version}

URL: https://journals.openedition.org/abstractairanica/51868

DOI: 10.4000/abstractairanica.51868

ISSN: 1961-960X

Publisher:

CNRS (UMR 7528 Mondes iraniens et indiens), Éditions de l'IFRI

\section{Electronic reference}

Shivan Mahandrajarah, "David Durand-Guédy, Roy Mottahedeh, Jürgen Paul (eds.). Cities of Medieval Iran", Abstracta Iranica [Online], Volume 42-43 | 2021, document 3, Online since 01 January 2020, connection on 13 December 2022. URL: http://journals.openedition.org/abstractairanica/51868 ; DOI: https://doi.org/10.4000/abstractairanica.51868

This text was automatically generated on 13 December 2022.

All rights reserved 


\title{
David Durand-Guédy, Roy Mottahedeh, Jürgen Paul (eds.). Cities of Medieval Iran
}

\author{
Shivan Mahandrajarah
}

\section{REFERENCES}

David Durand-Guédy, Roy Mottahedeh, Jürgen Paul (eds.). Cities of Medieval Iran. Leiden: Brill, 2020, vi $+495 \mathrm{p}$.

1 This volume is a reprint from Eurasian Studies, vol. 16, published in 2018, with an index. It consists of articles from a conference at Harvard University in 2015 on "Iranian Cities from the Arab Conquest to the Early Modern Period," and articles by scholars later invited to contribute. Included are thirteen original articles, and a translation of Jean Aubin's "Éléments pour l'étude des agglomérations urbaines dans l'Iran médiéval," which appeared in The Islamic City (eds., Hourani and Stern, Oxford, 1970). Islamic City dealt primarily with Arab lands, but this volume focuses on cities of the Iranian plateau. There are no essays on cities of the Persian Gulf, Khuzistan, and Caspian Sea littoral. A review by Jürgen Paul on the current state of scholarship about Islamic cities precedes the compendium.

2 Étienne de la Vaissière ("Inherited Landscapes of Muslim Bactra") offers archaeological evidence on Buddhist monasteries, irrigation networks of the Balkh oasis, and defense system, to demonstrate how the pre-Islamic past was either forgotten or reinterpreted by Muslims. Donald Whitcomb ("'From Shahristan to Medina Revisited") takes a 'bird's eye' view of urban patterns by examining cities in Fars and Khuzistan through archaeological works and aerial photography. He challenges Hugh Kennedy's views in "From Polis to Medina", but does not offer conclusions on Muslim acquisitions of Sasanian heritages. Jamsheed Choksy ("Yazd: a 'Good and Noble City' and an 'Abode of 
Worship"') explains how pre-Islamic heritages survived in irrigation systems and Yazd's confessionally diverse architectural styles.

Sarah Bowen Savant and Majid Mahdi ("The History of Iranian Cities through their Books [...]") examine one multi-text compilation ( $\operatorname{majmu} \bar{u}^{\prime} a$ ) produced in Injuid Shiraz (MS Köprülü 01589), which they show is source for social-economic history. Roy Mottahedeh ("Medieval Lexicography on Arabic and Persian Terms for City and Countryside") analyzes 5th/11th to 7th/13th century dictionaries having terms for cities, towns, farmlands, pastures, and deserts. He combines definitions in the dictionaries with information from geographers, to "form a more perfect picture of medieval Iranian society" (p. 465). He analyzes lexical terms in eleven categories: 'the city,' streets, suburbs, 'fortress and palace,' mosque, market, 'within the city,' 'local hierarchy,' 'town and village,' 'urban and rural,' and irrigation. This is a valuable reference.

Rocco Rante ("Iranian cities: Settlements and Water Management from Antiquity to the Islamic Period") examines how town and country were irrigated. Geomorphology and topography are considered. He offers examples from two dissimilar environments: the arid plateau, where subterranean channels (qanāt, kāriz) dominate; and Transoxiana, where above ground channels ( $n a h r, j \bar{u} y$ ) linked to rivers conveyed waters. The form of irrigation determined how a city grew, its layout, and its political-administrative center, which often was near good water. He includes case studies of Rayy, Nishapur, Marw, and Paykand. Richard Bulliet ("Why Nishapur?") offers geographic and socioeconomic reasons for Nishapur's economic prosperity. He posits that c. 1000 AD, Nishapur was the second largest city after Baghdad (p. 101). The reasons given include access by residents to qanāt-supplied water; the herding of camels; and a profitable cotton industry. Roy Mottahedeh and Mehrdad Amanat ("Medieval Kashan: Crossroads of Commerce and Culture") show how Kashan's remoteness let it thrive as a Shi' $i$ center. The Shi' $i$ families controlling Kashan improved it through public projects. The city was often controlled by rulers of Rayy or Isfahan, but Shi' $i$ elites had cordial relations with Sunni elites of Rayy and Isfahan. Kashan's prosperity is tied to qanātsupplied farming; trade routes; the nurturing of academic and artistic activities; and the building of charities and schools.

David Durand-Guédy ("Isfahan during the Turko-Mongol Period (11th-15th centuries)") reflects on Isfahan's political culture and reputation for disobedience. Three modes were employed by notables during crises: submission; forced collaboration with the stronger force; and where elites sought a new ruler or tried to remain independent. Self-rule was usually not an aspiration. Upper-echelon notables often made decisions for the lower socio-economic strata of Isfahan. Daniel Zakrewski ("Local elites and dynastic succession: Tabriz prior to, under and following Mongol Rule [...]") spans the Mongol to Safavid periods. Local elites participated in dynastic successions. Aspirants to a throne secured support from elites by offering stability. Urban notables retained their social/political statuses despite dynastic changes. Jürgen Paul ("Balkh, from the Seljuqs to the Mongol Invasion") examines the roles of elites. He shows that Seljuq Balkh's a'yān played decisive roles in administration, and in the application of Shari'a in a qād $\vec{\imath}$ 's court. Balkh was an example of the amir- $a^{\prime} y \bar{a} n$ system, which continued into the post-Seljuq period, but by then reflected political instabilities.

6 Ali S. Esfahani ("The Fortified Landscape of Isfahan") delivers an exposition on the fortifications around Isfahan. He used satellite imagery, field work, and literary 
sources. His conclusion is that a network of fortifications was strategically developed and emplaced to permit observation, communication, and defense. The defensive network protected and fostered human settlement and urban development.

Denise Aigle's ("Among Saints and Poets: The Spiritual Topography of Shiraz") focuses on sacred space (haram, hima), which exists in nearly every Iranian city. Shiraz, 'fortress of saints' (burj al-awliy $\vec{a}$ ), is unique: the whole city is sanctified. The chief holy sites are those of descendants of Imam 'Ali, Sufis, and poets. Aigle shows how Shiraz's sanctity is expressed in textual sources like Shīrāz-nāma and Shadd al-ïzār. She identifies the processes of sanctification, that is, how tombs acquire sanctity, such as from supernatural phenomena; for example, effusion of light, apparitions, and miracles. The 'shrine,' Aigle notes, 'is first and foremost a place of mediation between profane and sacred' (p. 169). It is the locus and the source of blessings (baraka), which suffuse the vicinity. It is also the locus of contact between supplicant and saint.

This book is an invaluable addition to the literature on medieval Iranian cities. The review by Jürgen Paul alone makes the volume an invaluable resource. Jean Aubin's article, translated here by Paul, makes Aubin's probing inquiries and thoughts accessible to a new generation of scholars. It is difficult, however, to commend or critique a composition that has many distinct components brought together from different academic perspectives, and in diverse academic styles. It is up to the reader to determine which of these articles suits their particular interests, hence the summaries. Articles by Mottahedeh (Arabic and Persian terms) and Aigle (sacred topography) are especially commended for the innovative approaches of their authors, but this should not detract from the importance of the other contributions.

\section{AUTHORS}

\section{SHIVAN MAHANDRAJARAH}

Institute of Iranian Studies, University of St Andrews 